\title{
Perceived Health Implications Of Harmful Traditional Practices On The Health Of Women Among Women Of Uruan Local Government Area Of Akwa Ibom State, Nigeria
}

\author{
DR. (MRS) Dorathy I. Achalu \\ Department of Physical and Health Education \\ University of Uyo, Akwa Ibom, Nigeria \\ DR. (MRS) Magareth Mboho \\ Department of Physical and Health Education \\ University of Uyo, Akwa Ibom, Nigeria
}

\begin{abstract}
The purpose of the study was to determine the perceived health implications of harmful traditional practices on health of women among women of Uruan Local Government Area of Akwa Ibom State, Nigeria. The study adopted descriptive research design. Three research questions were formulated to guide the study. Two hundred and ten women were randomly selected from seven villages in Uruan Local Government Area. Data were collected using a researchers' developed questionnaire. Data collected were analyzed using percentages to answer research questions. The result of the study showed that women in Uruan Local Government agree that there are health implications of harmful traditional practices which include among others, injury to reproductive organs during delivery in case of Female Genital Mutilation. Women are prone to developing hypertension because of the treatment meted to them at the death of their husbands. Also, women are exposed to mental depression because of not having male children for their husbands. Based on these findings, the researcher recommends among other things, that government and non-governmental organizations carry out campaign against these harmful traditional practices against women, and women could be encouraged to get quality educations.
\end{abstract}

\section{BACKGROUND}

Every human society has beliefs and practices that govern them. Some of these beliefs and practices are beneficial while some are harmful. Harmful traditional practices are long established patterns of actions or behaviour that are handed down from generations to generations (Agbara, 2012). The practices are based on beliefs and values held dearly by members of the society that indulge in such practices. Fran (1994) stated that the harmful traditional practices reflect values and beliefs held by members of a community from generations to generations. Harmful traditional practices also mean beliefs about issues that influence the ways of life of people in a particular society (Briggs, 2010).

Harmful traditional practices on women are customs and actions that are long established patterns of behaviour that are exhibited towards women that affect their health and wellbeing. Due to the effect on women's rights, Declaration to eliminate harmful traditional practices and violence against women was adopted during the World Conference on Woman's Rights at Vienna in 1993 (United Nation, 1990).

Female genital mutilation which is also referred to as "female circumcision" is a harmful traditional practice which involves the cutting of parts of a girl's genitalia (Olamola, 2004). 
According to WHO (2012) female genital mutilation is defined as all the procedures that involve partial or total removal of the female external genitalia for non-medical reasons, WHO further stated that it is practiced in more than 27 countries, Nigeria included. Olamola (2004) wrote that female genital mutilation is done as part of rite of passage into adulthood in some cultures, marking the coming of age of the female child, her sexuality control and to ensure a woman's virginity until she gets married.

Widowhood practices are those rites carried out on married women with or without children when they lose their husband to death. These practices include making the woman to sit on a mat all night; sleeping with the husband's corpse; wearing black clothes for six months to one year; drinking water used to wash the husband's corpse; shaving her hair; confined to a room where the husband's corpse was kept. Male child or son preference is a practice where couples prefer to have sons or male children to female children (Oluelaro, 2012). According to Ewchike (1984), male child or son preference is a situation where coiples prefer a son or male child to the girl or female child.

These harmful traditional practices have been present for so long that they have come to be accepted as part of the cultural norm in the societies where it is practiced by the entire population. The women who are the victims of the practice condone it. it is in this light that the United Nations international conference in 1994 with World Leader met to discuss the issue of harmful traditional practices on women and also X-ray its implications on the female gender. The pertinent question now is; how do women in Uruan Local Government Area perceive the health implications of harmful traditional practices on their health? Such harmful traditional practices include: Female genital mutilation, Widowhood practices, and male or son preference. The following research questions were formulated to guide the study:

- What are the health implications of female genital mutilation on health of women?

- What are the health implications of widowhood practices on women?

- What are the health implications of male child preference on health of women?

Uruan Local Government is one of 31 Local Governments in Akwa Ibom State, Nigeria. The Local Governments have seven clans or villages, which is headed by Clan Heads in each clan. The occupation of the people is mainly fishing. Uruan people have unique tradition which they express through their mode of dressing, dancing steps and masquerades. The population of Uruan Local Government Area is estimated to be 118,300 (National Census Commission, 2006).

\section{METHODOLOGY}

This study adopted descriptive research design in which a researcher's developed questionnaire was employed for data collection. The sample populations were 210 women. Thirty each were randomly selected from each clan, making up the total 210 women in Uruan Local Government Area. Simple percentages were used to analyse the data. 
RESULTS AND DISCUSSION

Table 1: Analysis of the Health Implications of Female Genital Mutilation on Health of Women in Uruan Local Government Area (N-210)

\begin{tabular}{|c|c|c|c|c|c|c|c|c|c|}
\hline $\begin{array}{l}\text { S/ } \\
\text { N }\end{array}$ & Items & SA & A & $\begin{array}{l}\text { Total } \\
\text { Agree }\end{array}$ & SD & D & $\begin{array}{l}\text { Total } \\
\text { Disagre } \\
\text { e }\end{array}$ & Total & Total \\
\hline 1 & $\begin{array}{l}\text { Mutilation } \\
\text { causes } \\
\text { excessive } \\
\text { bleeding }\end{array}$ & $\begin{array}{l}80 \\
\text { ) }\end{array}$ & $\begin{array}{l}60 \\
(28.6 \% \\
)\end{array}$ & $\begin{array}{l}140 \\
(66.7 \%)\end{array}$ & $\begin{array}{l}40 \\
(19 \%)\end{array}$ & $\begin{array}{l}30 \\
(14.3 \%)\end{array}$ & $\begin{array}{l}70 \\
(33.3 \%)\end{array}$ & 210 & 100 \\
\hline 2 & $\begin{array}{l}\text { Mutilation } \\
\text { results in } \\
\text { excessive } \\
\text { narrowing of } \\
\text { the opening } \\
\text { of the vagina }\end{array}$ & $\begin{array}{l}120 \\
(57.1 \%)\end{array}$ & $\begin{array}{l}55 \\
(22.6 \% \\
)\end{array}$ & $\begin{array}{l}175 \\
(83.3 \%)\end{array}$ & $\begin{array}{l}15 \\
(7.1 \%)\end{array}$ & $\begin{array}{l}20 \\
(9.5 \%)\end{array}$ & $\begin{array}{l}35 \\
(16.6 \%)\end{array}$ & 210 & 100 \\
\hline 3 & $\begin{array}{l}\text { Female } \\
\text { Genital } \\
\text { mutilation } \\
\text { causes gross } \\
\text { injury to the } \\
\text { reproductive } \\
\text { tracts during } \\
\text { delivery }\end{array}$ & $\begin{array}{l}100 \\
(47.6 \%)\end{array}$ & $\begin{array}{l}56 \\
(26.7 \% \\
)\end{array}$ & $\begin{array}{l}156 \\
(74.3)\end{array}$ & $\begin{array}{l}34 \\
(16.2 \%)\end{array}$ & $\begin{array}{l}20 \\
(9.5 \%)\end{array}$ & $\begin{array}{l}54 \\
(25.7 \%)\end{array}$ & 210 & 100 \\
\hline 4 & $\begin{array}{l}\text { Female } \\
\text { Genital } \\
\text { Mutilation } \\
\text { may end in } \\
\text { maternal } \\
\text { and infant } \\
\text { mortality }\end{array}$ & $\begin{array}{l}90 \\
(42.9 \%)\end{array}$ & $\begin{array}{l}60 \\
(28.6 \% \\
)\end{array}$ & $\begin{array}{l}150 \\
(71.5 \%)\end{array}$ & $\begin{array}{l}32 \\
(15.2 \%)\end{array}$ & $\begin{array}{l}28 \\
(13.3 \%)\end{array}$ & $\begin{array}{l}60 \\
(28.5 \%)\end{array}$ & 210 & 100 \\
\hline
\end{tabular}

The results in Table 1 show that 140 (66.7\%) respondents agreed that female genital mutilation causes excessive bleeding while 70 (33.3\%) disagreed. On narrowing of the opening of the vagina valve, 175 (83.3\%) agreed and 35 (17\%) disagreed. Respondents, 156 (74.3\%) agreed that female genital mutilation causes injury to the reproductive organs during delivery and $54(26 \%)$ disagree. On whether female genital mutilation can result in maternal and infant mortality, 150 (71.5\%) agreed and 60 (28.5\%) disagreed.

On the perceived health implications of female genital mutilation on the health of women, most women agreed that there are lots of health implications on health of women. Shandell (2012) supported these findings that female genital mutilation results in narrowed vaginal opening, gross injury to the reproductive tract, and maternal and infant mortality. This shows that women that had genital mutilation had obstructed labour and may die during child birth or lose the baby or both be lost during the process of giving birth if no caesarean section is performed in time to save the life of the woman and the baby. 
Achalu, D. I., \& Mboho, M. (2017). Perceived Health Implications Of Harmful Traditional Practices On The Health Of Women Among Women Of Uruan Local Government Area Of Akwa Ibom State, Nigeria. Advances in Social Sciences Research Journal, 4(7) 45-50.

Table 2: Analysis of the Health Implication of Widowhood Practices on Women in Uruan Local Government (N-210)

\begin{tabular}{|c|c|c|c|c|c|c|c|c|c|}
\hline$S / N$ & Items & SA & $\mathbf{A}$ & $\begin{array}{c}\text { Total } \\
\text { Agree }\end{array}$ & SD & D & $\begin{array}{l}\text { Total } \\
\text { Disagree }\end{array}$ & Total & Total \\
\hline 1 & $\begin{array}{l}\text { Practice of } \\
\text { not having } \\
\text { baths } \\
\text { exposes the } \\
\text { widows to } \\
\text { skin } \\
\text { infections }\end{array}$ & $\begin{array}{l}90 \\
(42.8 \%)\end{array}$ & $\begin{array}{l}54 \\
(25.7 \%)\end{array}$ & $\begin{array}{l}144 \\
(68.5 \%)\end{array}$ & $\begin{array}{l}43 \\
(20.5 \%)\end{array}$ & $\begin{array}{l}23 \\
(11 \%)\end{array}$ & $\begin{array}{l}66 \\
(31.5 \%)\end{array}$ & 210 & 100 \\
\hline 2 & $\begin{array}{l}\text { Eating with } \\
\text { unwashed } \\
\text { hands } \\
\text { exposes } \\
\text { widows to } \\
\text { diarrheal } \\
\text { diseases } \\
\end{array}$ & $\begin{array}{l}98 \\
(46.7 \%)\end{array}$ & $\begin{array}{l}44 \\
(20.9 \%)\end{array}$ & $\begin{array}{l}142 \\
(67.6 \%)\end{array}$ & $\begin{array}{l}30 \\
(14.2 \%)\end{array}$ & $\begin{array}{l}38 \\
(18.2 \%)\end{array}$ & $\begin{array}{l}68 \\
(32.4 \%)\end{array}$ & 210 & 100 \\
\hline 3 & $\begin{array}{l}\text { An inherited } \\
\text { widow is } \\
\text { vulnerable to } \\
\text { sexually } \\
\text { transmitted } \\
\text { infections for } \\
\text { other man }\end{array}$ & $\begin{array}{l}70 \\
(33.3 \%)\end{array}$ & $\begin{array}{l}40 \\
(19 \%)\end{array}$ & $\begin{array}{l}110 \\
(52.3 \%)\end{array}$ & $\begin{array}{l}60 \\
(28.6 \%)\end{array}$ & $\begin{array}{l}40 \\
(19 \%)\end{array}$ & $\begin{array}{l}100 \\
(47.6 \%)\end{array}$ & 210 & 100 \\
\hline 4 & $\begin{array}{l}\text { Observance } \\
\text { of night vigil } \\
\text { by the } \\
\text { widow } \\
\text { exposes her } \\
\text { to risk of } \\
\text { hypertension }\end{array}$ & $\begin{array}{l}100 \\
(47.6 \%)\end{array}$ & $\begin{array}{l}94 \\
(44.7 \%)\end{array}$ & $\begin{array}{l}194 \\
(92.3 \%)\end{array}$ & $\begin{array}{l}13 \\
(6.2 \%)\end{array}$ & $\begin{array}{l}3 \\
(1.4 \%)\end{array}$ & $\begin{array}{l}16 \\
(7.6 \%)\end{array}$ & 210 & 100 \\
\hline
\end{tabular}

Table 2 shows the responses on perceived health implications of widowhood practices on women, 144 (68\%) agreed that not having baths during mourning period exposes the widow to skin infections and 66 (31.5\%) disagreed to that. On eating with unwashed hands exposing widow to diarrheal diseases and other health infections, $142(67.6 \%)$ agreed to that while 68 (32.4\%) disagreed. When women are inherited, they are vulnerable to sexually transmitted diseases, 110 (52.3\%) agreed and 100 (47.6\%) disagreed. On observance of night vigil by the widow exposes her to risk of hypertension, 194 (92.3\%) agreed while 16 (7.6\%) disagreed.

The findings agreed with the report of Genyi (2013) on widowhood practice in Nigeria and support systems. Genyi found out that widowhood is generally traumatic for widows due to the dehumanizing treatment widows are exposed to. Another author stated that most traditional practices in Nigeria regarding widows are aimed at intimidating, subduing and humiliating women as a way of sustaining the culture of obedience, rendering then perpetually subservient to men (Onyebukwa, Hamlim and Bassey, 2016). The practice makes women less able to cater for the family as most of the late husband's properties are confiscated and this can cut short many widow's lives as they become stressed, sick and die prematurely. 
Table 3: Analysis of the Health Implications of Male Child or Son Preference on the Health of Women in Uruan Local Government Area (N-210)

\begin{tabular}{|c|c|c|c|c|c|c|c|c|c|}
\hline $\begin{array}{l}\text { S/ } \\
\mathrm{N}\end{array}$ & Items & SA & A & $\begin{array}{l}\text { Total } \\
\text { Agree }\end{array}$ & SD & D & $\begin{array}{l}\text { Total } \\
\text { Disagree }\end{array}$ & Total & Total \\
\hline 1 & $\begin{array}{l}\text { Son preference } \\
\text { exposes } \\
\text { women to } \\
\text { frequent } \\
\text { pregnancies }\end{array}$ & $\begin{array}{l}100 \\
(47.6 \% \\
)\end{array}$ & $\begin{array}{l}96 \\
(45.7 \%)\end{array}$ & $\begin{array}{l}196 \\
(93.3 \% 0\end{array}$ & $\begin{array}{l}11 \\
(5.2 \%)\end{array}$ & $\begin{array}{l}3 \\
(1.4 \%)\end{array}$ & $\begin{array}{l}14 \\
(6.6 \%)\end{array}$ & 210 & 100 \\
\hline 2 & $\begin{array}{l}\text { Male child } \\
\text { pregnancies } \\
\text { subject women } \\
\text { to } \\
\text { complication } \\
\text { during } \\
\text { delivery } \\
\end{array}$ & $\begin{array}{l}74 \\
(35.2 \% \\
)\end{array}$ & $\begin{array}{l}73 \\
(34.8 \% 0\end{array}$ & $\begin{array}{l}147 \\
(70 \%)\end{array}$ & $\begin{array}{l}33 \\
(15.7 \%)\end{array}$ & $\begin{array}{l}30 \\
(14.3 \%)\end{array}$ & $\begin{array}{l}63 \\
(30 \%)\end{array}$ & 210 & 100 \\
\hline 3 & $\begin{array}{l}\text { Son preference } \\
\text { exposes } \\
\text { women to } \\
\text { sexually } \\
\text { transmitted } \\
\text { infections } \\
\text { because of the } \\
\text { possibility of } \\
\text { polygamy }\end{array}$ & $\begin{array}{l}70 \\
\text { (33.3\% } \\
\text { ) }\end{array}$ & $\begin{array}{l}70 \\
(33.3 \%)\end{array}$ & $\begin{array}{l}140 \\
(66.6 \% \\
)\end{array}$ & $\begin{array}{l}40 \\
(19 \%)\end{array}$ & $\begin{array}{l}30 \\
(14.3 \%)\end{array}$ & $\begin{array}{l}70 \\
(33.3 \%)\end{array}$ & 210 & 100 \\
\hline 4 & $\begin{array}{l}\text { Male child } \\
\text { preference } \\
\text { exposes } \\
\text { women to } \\
\text { mental stress } \\
\text { and depression }\end{array}$ & $\begin{array}{l}84 \\
(40 \%)\end{array}$ & $\begin{array}{l}54 \\
(25.7 \%)\end{array}$ & $\begin{array}{l}138 \\
(65.7 \%)\end{array}$ & $\begin{array}{l}40 \\
(19.6 \%)\end{array}$ & $\begin{array}{l}32 \\
(15.2 \%)\end{array}$ & $\begin{array}{l}72 \\
(34.3 \%)\end{array}$ & 210 & 100 \\
\hline
\end{tabular}

Analysis of the perceived health implications of male child or son preference on the health of women in Table 3 is as follows. A total of 196 women (93.3\%) agreed that the practice exposes women to frequent pregnancies while 14 (6.6\%) disagreed; on complication during delivery, 147 (70\%) agreed that women are exposed to complication during delivery and 63 (30\%) disagreed. Women are exposed to sexually transmitted diseases because of the possibility of polygamy, 140 (66.6\%) agreed while 70 (33.3\%) disagreed. The male child preference exposes women to mental stress and depression, 138 (65.7\%) agreed while 72 (34.3\%) disagreed.

The findings of perceived health implications of son or male child preference on the health of women has shown that most respondents agreed that women are exposed to complications and mental depression as a result of not having a male child. Adsera (2014) revealed that women can do anything to have a son or a male child more than a female child. Women can go through anything to see that they deliver a male child in order to satisfy the need of their husband and family, and also to establish strong hold in husband's life, not minding the effect on their health. This act of seeking a male child takes away their Women Contraceptive Rights and leads to negligence in health. Genatra and Johnson (2002), in a study conducted in Bangladesh showed that $92 \%$ of families preferred to have a son, seeing that as a blessing to home and country. Because of that, many mothers would conceive frequently in order to give birth to a male child, and to discourage their husbands from taking other wives.

In conclusion, the findings of this study prove that women in Uruan Local Government Area, Akwa Ibom State, Nigeria, agree that there are health implications of harmful traditional 
practices which include, among others, genital mutilation, widowhood practice and male child or son preference on women.

\section{RECOMMENDATIONS}

- Government and non-government organizations should help campaign against these harmful traditional practices against women.

- Women should be encouraged to get quality education. Parents should send their female children to school, encourage them to learn a trade or at least have a means of self-support. This will help them to live independently and be able to support their children on the unfortunate event of their husbands' death.

- Government should enact laws that will protect women from harmful traditional practices and make sure that the law is well implemented.

- Government and non-government organizations should educate women on their rights and how they should stand up and defend it.

\section{References}

Agbara, C. J. (2012). Inequality and discrimination in Nigeria Tradition and Religion as negative factors affecting gender. National Council for Arts and Culture, Lagos; Nigeria

Adsera, A. (2014). Son preference and Children's house work; the case of India. New Jersey Princeton University, Woodrow Wilson School of Public and International Affairs.

Briggs, L. A. (2010). Issues in Health Education. Abuja: Timi Hyacinth

Ewehika, U. U. (2002) Post Colonialism, Gender Customary in Justice. Ibadan: Nigeria Royal Publishing Co. Ltd.

Fran, P. H. (1994). The Hosken Report Genital and Sexual Mutilation of Females (4th ed). Lexington Mass Women International Network News Massachusetts: United States Lexington Press.

Ganatra, B. and Johnson, R. (2002). Unsafe Abortions. WHO Geneva

Genyi, G. (2013). Widow and Nigeria Womanhood: Another context of gendered poverty in Nigeria. International Research on Humanities and Social Sciences. Journal of Institute for Science, Technology and Education. 3 (M): 68 $-74$

Nigeria Population Census Commission (NPC, 2006), Figures of Population in Nigeria. Accessed September 25, 2016 at http://www.nig.master.web.com.nig06C

Olamola, O. (2004). Unending Harmful Tradition Shrouded in Secrecy: Female Genital Mutilation. Ibadan: Nigeria Royal People Ltd.

Oluduro, O. (2012). Son Preference in Nigeria: The Human Rights Implications. Unpublished Ph.D. Thesis. Faculty of Law, Adekime Ajasin University, Ondo State, Nigeria.

Onyebukwa, V. Hamlim, K. and Bassey, V. W. (2016). Battered Abandoned: Tales of Inheritance and Widow's Battle for Survival. Saturday Sun. September 24, $24-15$

Shandell, A. A. (2012). Circumcision and Infibulations of Females: A general Consideration of the problem and Clinical Study of the Complications in Sudanese Women. Geneva: WHO Publication

United Nations General Assembly (1993). Declaration on the elimination of violence against women. Proceedings of the $85^{\text {th }}$ Plenary Meeting, Geneva

World Health Organization (2012). Female Genital Mutilation Information Fact Sheet (241) WHO: Geneva 